\title{
PENGEMBANGAN PEMBELAJARAN STATISTIK BERBASIS IT MENGGUNAKAN PENDEKATAN REALITIC MATHEMATICS EDUCATION UNTUK MAHASISWA TEKNIK SIPIL
}

\author{
Nur Aida ${ }^{1)}$ \\ 1) Politeknik Negeri Ketapang, Ketapang \\ E-mail: nhuraidha@ gmail.com
}

\begin{abstract}
Abstrak. Matakuliah statistik adalah matakuliah yang digunakan mulai dari aktivitas di laboratorium, riset dan berbagai aktivitas dalam pengelolaan pemerintahan. Untuk itu dosen pengampu matakuliah diharapkan dapat mengembangkan pembelajaran yang lebih aktif, kreatif, efektif dan menyenangkan dalam proses pembelajaran. Materi statistika yang diajarkan disusun dengan tujuan membantu mahasiswa dalam memahami dan menangani ketidakpastian, variabilitas dari informasi statistik yang diperoleh. Selain itu diharapkan mahasiswa dapat menguasai berbagai aplikasi statistik dan dapat menerapkan dalam kehidupan sehari-hari atau bidang studi lain. Tujuan dari penelitian ini adalah untuk mengetahui efektivitas pembelajaran Statistik berbasis IT menggunakan pendekatan RME untuk mahasiswa Teknik Sipil. Dari hasil evaluasi pada tahap penilaian (assesment) dilaksanakan Field test atau uji lapangan dimana nilai kelompok mahasiswa diatas 85 dan kuisioner akhir semester untuk mata kuliah statistik sangat baik. Uji lapangan dilakukan pada sekelompok mahasiswa yang berada pada kelas semester dua tahun akademik 2018/2019 Jurusan Teknik Sipil, program studi Perancangan Jalan dan Jembatan. Diketahui bahwa RME berbasi IT meningkatkan pemahaman mahasiswa dan mendorong mahasiswa untuk memahami keterkaitan matematika dengan dunia sekitar, terlibat langsung dalam proses belajar, melalui belajar berkelompok serta terlatih untuk menghargai pendapat orang lain.
\end{abstract}

Kata Kunci: RME, persamaan regresi dan korelasi.

\section{PENDAHULUAN}

Statistik memegang peranan penting dalam pendidikan terutama dalam kehidupan manusia. Statistik digunakan mulai dari aktivitas di laboratorium, riset dan berbagai aktivitas dalam pengelolaan pemerintahan. Oleh karena itu, pemahaman dasar mahasiswa akhir terhadap statistika sangat diperlukan dan sangat mendasar. Untuk itu dosen pengampu matakuliah diharapkan dapat mengembangkan pembelajaran yang menggunakan media pembelajaran yang lebih menekankan kepada pembandingan dari suatu analisa data selain secara manual. Pembelajaran yang biasa digunakan, dosen yang lebih aktif dengan memberikan contoh atau latihan dan rumus sehingga mahasiswa menerima informasi berupa rumus yang ada kemudian dosen memberikan soal untuk mahasiswa kerjakan. Disisi lain mahasiswa hanya berperan mendengarkan, mencatat, dan mengerjakan latihan yang telah diberikan. Pengetahuan mahasiswa hanya sampai tahap mengenali, mengingat dan memahami saja dan belum terbiasa kepada tahap evaluasi atau bernalar statistik. Ini dapat dilihat dari evaluasi pembelajaran yang dilakukan di akhir semester pada tahun akademik sebelumnya.

Statistik merupakan matakuliah wajib yang harus diberikan kepada mahasiswa di semester dua (semester genap) di program studi Perancangan Jalan dan Jembatan, Jurusan Teknik Sipil, Politeknik Negeri Ketapang. Deskripsi matakuliah tersebut tentang konsep dasar statistik dan probabilitas, yang menekankan pada pengumpulan data, merangkum data, menganalisa data dan menyimpulkan data untuk digunakan dalam memecahkan masalah sederhana dalam pengolahan data di bidang rekayasa teknik sipil. Ruang lingkup materi yang diajarkan dari matakuliah statistik adalah pengertian statistik dan statistika, peran statistik dalam penelitian ilmiah, macam-macam statistik, data statistik, variabel penelitian, penyajian data dalam distribusi frekuensi, ukuran statistik, peluang, aturan peluang, distribusi probabilitas diskrit, distribusi probabilitas kontinu dan fungsi probabilitas, hipotesis dan uji regresi dan korelasi. Mahasiswa diharapkan dapat memahami dan menguasai konsep tersebut.

Konsep persamaan regresi dan korelasi merupakan konsep yang sering digunakan untuk analisis data-data penelitian khususnya bidang teknik sipil. Kedua konsep 


\section{- - - Jurnal Pendidikan Matematika Indonesia \\ Volum 5 Nomor 1 bulan Maret 2020 Page 39 - 45 \\ p-ISSN: 2477-5967 e-ISSN: 2477-8443}

tersebut saling berkaitan. Setiap perhitungan regresi selalu didahului dengan perhitungan korelasi akan tetapi tidak sebaliknya. Jika ada perhitungan korelasi belum tentu dilanjutkan dengan perhitungan regresi. Pada ilmu statistika untuk mengetahui hubungan antara dua variebel maka diperlukan konsep regresi dan korelasi. Apabila variabel tersebut mempunyai hubungan, maka nilai salah satu variabel yang sudah diketahui dapat dipergunakan untuk menafsirkan terjadinya suatu kejadian lainnya.

Pembelajaran statistik diharapkan dapat membentuk dan mengembangkan kemampuan penalaran statistik mahasiswa dalam menganalisis serta mengevaluasi hasil yang diperoleh. Menurut Garfield dan Chance (2000), penalaran statistik terdiri dari bagaimana mahasiswa berlogika dengan ide-ide yang telah diterima, memahami informasi tersebut, kemudian membuat interpretasi berdasarkan data yang ada, memberikan lambang terhadap data, dan akhirnya membuat ringkasan statistik data. Menurut Ratna Sariningsih dan Indri Herdiman (2017), kemampuan penalaran statistik terkait dengan kemampuan seseorang dalam memahami konsep-konsep dasar dan logika dalam memilih rumus, menggunakan dan menganalisis metode deskriptif atau inferensial yang akan digunakan dengan cara yang tepat. Materi statistika yang akan dipelajari oleh mahasiswa disusun dengan tujuan membantu mahasiswa dalam memahami dan menangani ketidakpastian, keberagaman dari informasi statistik yang diperoleh, sehingga diharapkan mahasiswa dapat menguasai berbagai aplikasi statistik dan dapat menerapkan dalam kehidupan sehari-hari khususnya bidang teknik sipil.

Media pembelajaran berbasis komputer merupakan salah satu pembelajaran yang dapat meningkatkan kemampuan penalaran statistik bagi mahasiswa. Bantuan komputer dengan berbagai aplikasi yang sudah ada dapat membuat pembelajaran lebih menarik, karena bisa mengolah data dan menampilkan grafik secara lebih mudah dan langsung. Pembelajaran Realistic Mathematisc Education (RME) merupakan salah satu pendekatan dalam pembelajaran yang dapat memfasilitasi mahasiswa untuk penalaran statistik. RME adalah pembelajaran matematika yang mengajak mahasiswa untuk menerapkan materi pelajaran yang diperoleh ke dalam kehidupan sehari-hari. Ketika proses pembelajaran, dosen tidak langsung menginformasikan rumus atau konsep kepada mahasiswa, tetapi mahasiswa diarahkan untuk menemukan atau membangun sendiri konsep yang dipelajari.

Menurut Zulkardi (2006), pembelajaran dengan teori RME terdiri dari lima karakteristik yaitu : pemakaian real konteks sebagai dasar dalam belajar matematika, pemakaian model yang menekankan penyelesaian secara informal sebelum menggunakan rumus, menghubungkan berbagai topik dalam matematika, metode pembelajaran lebih interaktif, dan menghargai berbagai macam jawaban dan partisipasi siswa dalam menjawab. Dalam penelitian ini real konteks diperoleh dari data artikel hasil penelitian, kemudian mahasiswa menentukan rumus yang akan digunakan, mahasiswa juga bekerjasama dalam kelompok.
Menurut penelitian sebelumnya Utari (2003) dalam Edy Tandililing (2010), pembelajaran dengan menggunakan pendekatan realistik lebih dapat meningkatkan pemahaman siswa dan pembelajaran siswa lebih bermakna, mendorong siswa untuk memahami keterkaitan matematika dengan kehidupan sehari-hari, dalam proses belajar siswa akan lebih terlibat langsung dengan belajar berkelompok sehingga terlatih untuk menghargai pendapat orang lain.

Konsep RME dapat digunakan untuk memperbaiki pendidikan yang memiliki pandangan tentang dosen, dimana dosen hanya sebagai fasilitator dalam belajar, dosen diharapkan dapat membentuk pembelajaran yang interaktif, dan dosen bisa menghubungkan kurikulum yang ada dengan dunia nyata secara fisik maupun sosial. Pembelajaran yang interaktif adalah pembelajaran yang berbasis IT dengan dukungan teknologi untuk mempermudah proses belajar mahasiswa pada materi persamaan regresi dan korelasi.

Menurut Suryanto (2007), RME memiliki ciri-ciri khusus yaitu siswa dihadapkan dalam masalah kontekstual yang realistik untuk mengenali konsep-konsep baru dalam pembelajaran, siswa dipersilahkan memecahkan masalah tersebut, setelah ditemukan cara bagaimana menyelesaikan masalah tersebut siswa diarahkan untuk secara kelompok mendiskusikan penyelesaianya, kemudian merefleksi apa yang telah dikerjakan. Penerapan RME didalam proses pembelajaran terdiri dari tiga tahap yaitu: pengenalan, eksplorasi dan meringkas. Pada tahap pengenalan ini, dosen menginformasikan masalah realistik dalam matematika kepada seluruh mahasiswa dan diharapkan mahasiwa dapat memahami masalah yang ada. Adapun masalah dalam penelitian ini diperoleh dari artikel-artikel bidang Teknik Sipil. Pada tahap eksplorasi, mahasiswa diharapkan bekerja secara individual atau berkelompok. Peran dosen dalam tahap ini memberikan bantuan seperlunya kepada mahasiswa yang membutuhkan saja. Setelah mahasiswa menunjukkan kemajuan dalam pemecahan masalah, dosen dapat memberikan pekerjaan lanjutan kepada mahasiswa berupa ringkasan kesimpulan apa yang bisa diambil oleh mahasiswa. Diharapkan mahasiswa dapat membuat keterkaitan antara materi yang dipelajari.

\section{METODE PENELITIAN}

Penelitian ini menggunakan penelitian deskriptif. Tujuan penelitian ini adalah untuk mengembangkan model pembelajaran yang lebih efektif pada matakuliah statistik khususnya materi persamaan regresi dan korelasi bagi mahasiswa. Subyek penelitian ini adalah mahasiswa semester dua (2) Program Studi Perancangan Jalan dan Jembatan Jurusan Teknik Sipil Politeknik Negeri Ketapang tahun akademik 2018/2019 sebanyak 57 orang mahasiswa. Teknik pengumpulan data berupa dokumentasi hasil pekerjaan mahasiswa pada tugas dan ujian akhir semester (UAS). Penelitian ini menggunakan pendekatan kualitatif. Adapun pendekatan kualitatif digunakan ketika menganalisis jawaban mahasiswa.

Penelitian dimulai dengan analisis pendahuluan, berupa analisis kebutuhan, kurikulum, konsep, mahasiswa dan melakukan evaluasi literatur ilmiah. Evaluasi literatur 


\section{- - - Jurnal Pendidikan Matematika Indonesia \\ Volum 5 Nomor 1 bulan Maret 2020 Page 39 - 45 \\ p-ISSN: 2477-5967 e-ISSN: 2477-8443}

ilmiah dilakukan setelah penilaian tugas kelompok. Berdasarkan empat analisis pendahuluan tersebut maka dirancanglah desain pembelajaran pada materi persamaan regresi dan korelasi berbasis RME pada mahasiswa semester dua.

Untuk melakukan analisis kurikulum, peneliti melakukan telaah kepada kurikulum yang digunakan untuk materi persamaan regresi dan korelasi untuk mahasiswa semester dua. Tujuan analisis ini untuk mengetahui cakupan materi, tujuan pembelajaran dan startegi yang akan dipilih sebagai dasar dalam mengembangkan pembelajaran agar tujuan pembelajaran yang diharapkan tercapai dengan maksimal. Dosen menganalisis indikator-indikator yang diharapkan agar kompetensi pembelajaran tercapai.

Untuk memperoleh kebutuhan apa yang diharapkan dari mahasiswa sebagai target penggunaan media IT yang akan dikembangkan, maka dilakukanlah analisis peserta didik (mahasiswa). Untuk menentukan konsep mana yang dibutuhkan dalam pengembangan perangkat pembelajaran sehingga indikator-indikator dalam pembelajaran bisa tercapai secara maksimal maka dilakukanlah analisis konsep.

Pada tahap penilaian (assessment) ini dilakukan uji pengembangan pembelajaran. Uji pengembangan pembelajaran ini berupa uji lapangan (Field Test) yang dilakukan kepada sekelompok mahasiswa pada beberapa kelas semester dua tahun akademik 2018/2019 Jurusan Teknik Sipil, program studi Perancangan Jalan dan Jembatan. Penilaian dalam uji lapangan ini dilakukan untuk mengetahui seberapa efektif, praktis dan untuk mengetahui mutu dari hasil desain pembelajaran tersebut apakah telah sesuai dengan harapan untuk mengembangkan kemampuan penalaran mahasiswa.

\section{HASIL DAN PEMBAHASAN}

Pembelajaran dimulai dengan dosen memberikan topik materi yang akan dipelajari. Setelah itu mahasiswa berkelompok dan mencari artikel Teknik Sipil yang sesuai dengan konsep tersebut. Tujuannya mahasiswa bisa menemukan sendiri konsep persamaan regresi dan korelasi, dan melakukan pengujian secara nyata berdasarkan data yang ada pada artikel. Dalam Nana Sudjana (2009), tipe hasil belajar aplikasi adalah menerapkan abstraksi ke dalam situasi baru, menerapkan persamaan regresi dan perhitungan korelasi ke dalam persoalan teknik sipil. Mahasiswa diharapkan dapat memberikan evaluasi tentang hasil analisis yang telah dilakukan oleh penulis artikel tersebut.

Mahasiswa akan melakukan diskusi secara kelompok, diakhir pembelajaran dosen menjelaskan hal-hal yang dianggap kurang jelas, menguraikan tentang persamaan regresi dan korelasi secara manual dan perhitungan dengan bantuan aplikasi Microsoft excel dan SPSS 16.0 dimana setiap mahasiswa mendapatkan hand out materi persamaan regresi dan korelasi. Dosen memberikan gambaran bahwa hasil perhitungan manual dan dengan bantuan IT tidak berbeda. Pada saat ini terjadi evaluasi literatur ilmiah, jika pada suatu artikel terjadi kesalahan perhitungan, maka hasil yang berbeda akan diperoleh antara yang telah dilakukan oleh kelompok dengan yang dilakukan oleh penulis dalam artikel tersebut.

Efektifitas pembelajaran dapat dilihat dari nilai akhir yang mahasiswa peroleh pada tahap evaluasi yaitu nilai ratarata tugas mahasiswa di atas 89 (Gambar 10) dan besarnya nilai kuisioner penilaian mahasiswa pada akhir semester pada sistem informasi akademik Politeknik Negeri Ketapang untuk matakuliah yang telah diampu. Dimana nilai kuisioner yang diperoleh untuk mata kuliah Statistik adalah 3,53 dengan nilai sangat baik (Gambar 11). Secara keseluruhan untuk perkuliahan statistik dilakukan dengan pembelajaran berbasis IT, tidak hanya pada materi yang dibahas saja.

Pembelajaran yang dirancang difokuskan pada pengembangan kemampuan penalaran mahasiswa materi persamaan regresi dan korelasi dan untuk mahasiswa semester dua. Dalam penelitian ini dilakukan dalam dua tahap, pertama konsep persamaan regresi harus ditemukan terlebih dahulu oleh mahasiswa, baru mahasiswa menemukan konsep rumus korelasi. Untuk menemukan konsep, mahasiswa harus memahami masalah konstekstual yaitu tentang penyajian data yang berhubungan dengan Jurusan yang telah mahasiswa ambil yaitu Teknik Sipil. Data yang akan diolah atau dihitung diperoleh dari data penelitian dari artikel-artikel pada jurnal yang berhubungan dengan Teknik Sipil. Setelah mahasiswa menemukan konsep rumus persamaan regresi mahasiswa kemudian menghitung data yang diperoleh secara manual kemudian apakah sesuai dengan hasil perhitungan pada artikel tersebut. Untuk meningkatkan penalaran mahasiswa mengenai konsep persamaan regresi maka dosen menginformasikan bahwa hasil tersebut dapat dibuktikan menggunakan aplikasi microsoft excel dan SPSS. Sehingga penggunaan aplikasi tersebut merupakan target penggunaan media IT dalam pembelajaran.

Kedua, menemukan konsep rumus korelasi. Aktivitas pembelajaran dimulai dengan masalah yang ada pada artikel yang sama yang telah ditentukan oleh mahasiswa itu sendiri. Aktivitas ini membuat mahasiswa lebih memahami hubungan antara dua variabel, variabel bebas dan variabel terikat yang ada pada artikel tersebut. Akhir dari pembelajaran adalah mahasiswa dapat membuat grafik persamaan regresi dan mengetahui nilai korelasi hubungan dari dua variabel tersebut. Hubungan tersebut bisa positif atau negatif didasari dari nilai $r$ nya. Tanda negatif atau positif pada bilangan $r$ menunjukkan arah perubahan pada satu variabel terhadap perubahan variabel lainnya, artinya jika $r$ negatif apabila kenaikan perubahan pada suatu variabel menyebabkan penurunan perubahan variabel lain, sedangkan $r$ positif jika perubahan kedua variabel tersebut menuju arah yang sama. Nilai $r$ dibatasi oleh harga -1 dan +1 (Adang Surahman, 2016).

Adapun konsep penyajian data selama ini hanya diberikan langsung oleh dosen tanpa memberikan kesempatan kepada mahasiswa untuk mengkonstruksi sendiri. Field Test dilakukan kepada semua mahasiswa semester dua sebanyak 57 orang mahasiswa.

Mahasiswa dikelompokkan menjadi 10 kelompok karena tidak semua mahasiswa mempunyai komputer. Setiap 
kelompok terdiri dari 5-6 orang mahasiswa. Kegiatan pembelajaran dilakukan secara kelompok agar mahasiswa tercipta sikap saling menghargai, peduli (tenggang rasa, gotong royong), santun, percaya diri dalam berinteraksi dalam lingkungan sosial. Dosen menyiapkan proses pembelajaran dengan menyediakan RPP, media IT, dan artikel. Pada akhir proses pembelajaran dilakukan diskusi kelas. Adapun deskripsi hasil evaluasi pembelajaran yaitu:

1. Pembelajaran untuk konsep persamaan Regresi

Mahasiswa mampu mengecek jawaban hasil perhitungan pada artikel tersebut dengan perhitungan manual, dan menggunakan aplikasi microsoft excel dan SPSS. Dalam perhitungan terlihat mahasiswa bisa melakukan perhitungan yang hasilnya sama dengan perhitungan pada artikel tersebut dan mahasiswa semakin yakin dengan perhitungan yang dilakukan karena sama dengan hasil penggunaan aplikasi tersebut yang telah mereka lakukan.

Adapun contoh dari jawaban mahasiswa pada salah satu kelompok disajikan pada Gambar 2, 3 dan 5 berikut. Adapun data yang mahasiswa gunakan berasal dari artikel yang ditulis oleh Aris Sustrisno dan Slamet Widodo (2012) dengan judul "Analisis Variasi Kandungan Semen terhadap Kuat Tekan Beton Ringan Struktural Agregat Pumice" Program Studi Teknik Sipil Fakultas Teknik, Universitas Negeri Yogyakarta.

TABEL I

BENDA UJI BETON RINGAN

\begin{tabular}{cc}
\hline Semen $\left(\mathbf{k g} / \mathbf{m}^{3}\right)$ & Berat Jenis Rerata $\left(\mathbf{k g} / \mathbf{m}^{\mathbf{3}}\right)$ \\
\hline $\mathbf{3 0 0}$ & 1823,29 \\
$\mathbf{3 5 0}$ & 1856,81 \\
$\mathbf{4 0 0}$ & 1855,62 \\
$\mathbf{4 5 0}$ & 1861,45 \\
\hline
\end{tabular}

Sumber : Aris Sustrisno dan Slamet Widodo (2012)

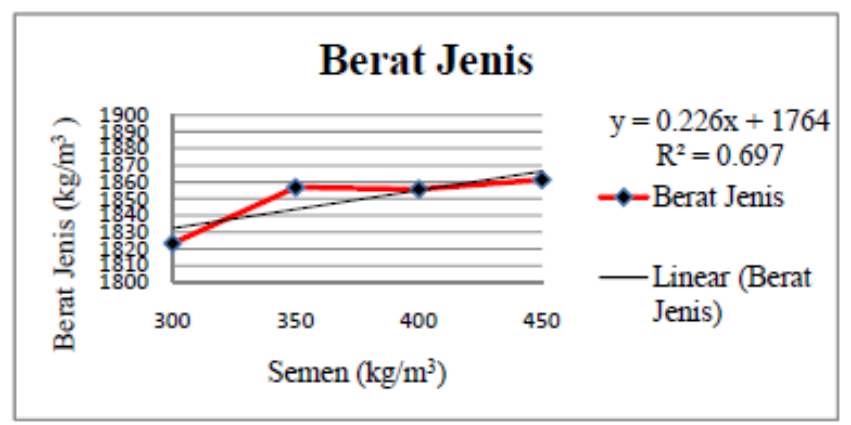

Gambar 1 Grafik hubungan berat semen yang digunakan terhadap bera jenis beton ringan (Aris Sustrisno dan Slamet Widodo, 2012)

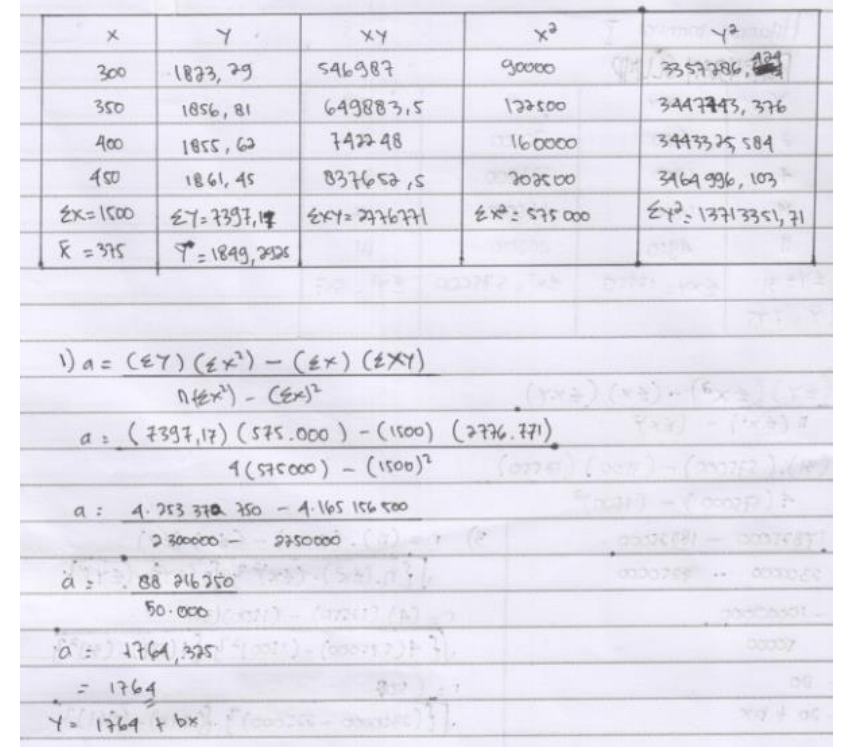

Gambar 2a. Hasil analisis mahasiswa secara manual untuk nilai a pada persamaan regresi

2). $\begin{aligned} b & =\frac{n(\varepsilon x y)-(\Sigma x)(\Sigma y)}{n\left(\Sigma x^{2}\right)-(\varepsilon x)^{2}} \\ b & =\frac{4(2.776 .771)-(1500)(7397,17)}{4(575000)-(1500)^{2}} \\ b & =\frac{11.107089-11.095775}{2.300000-2250000} \\ b & =\frac{11329}{50000} \\ b \quad & 0,22658\end{aligned}$

Gambar 2b. Hasil analisis mahasiswa secara manual untuk nilai b pada persamaan regresi

Berdasarkan Gambar 2a dan $2 \mathrm{~b}$ di atas terlihat bahwa hasil perhitungan yang telah dilakukan oleh salah satu kelompok mahasiswa menunjukkan hasil yang sama dengan Gambar 1 grafik yang diperoleh dari artikel tersebut. Dari gambar grafik memperlihatkan bahwa persamaan regresi yang telah diperoleh adalah $y=0,226 x+1764$. Sehingga jika dibandingkan dengan hasil perhitungan mahasiswa secara manual maka nilai tersebut adalah sama. Mahasiswa juga melakukan analisis dengan bantuan aplikasi microsoft excel dan SPSS 16.0, seperti terlihat pada Gambar 3 dan 4 berikut. Berdasarkan analisis tersebut maka dapat diketahui nilai akhirnya hampir sama dengan hasil pada artikel tersebut. 


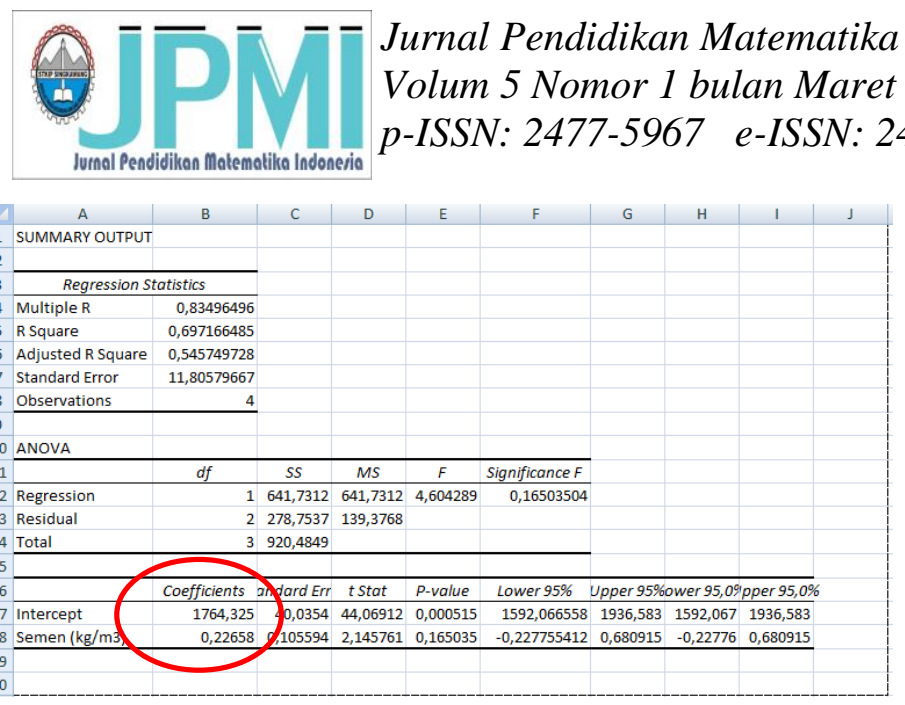

Gambar 3 Hasil analisis mahasiswa dengan aplikasi microsoft excel

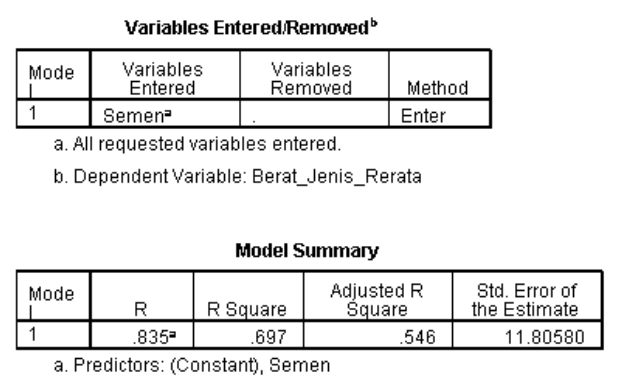

\begin{tabular}{|ll|r|r|r|r|c|}
\multicolumn{7}{|c|}{ ANOVA $^{\text {b }}$} \\
\hline Madel & & $\begin{array}{c}\text { Sum of } \\
\text { Squares }\end{array}$ & \multicolumn{1}{c|}{ df } & Mean Square & F & Sig. \\
\hline 1 & Regression & 641.731 & 1 & 641.731 & 4.604 & $.165^{\mathbf{a}}$ \\
& $\begin{array}{l}\text { Residual } \\
\text { Total }\end{array}$ & 278.754 & 2 & 139.377 & & \\
\hline
\end{tabular}

a. Predictors: (Constant), Semen

b. Dependent Variable: Berat_Jenis_Rerata

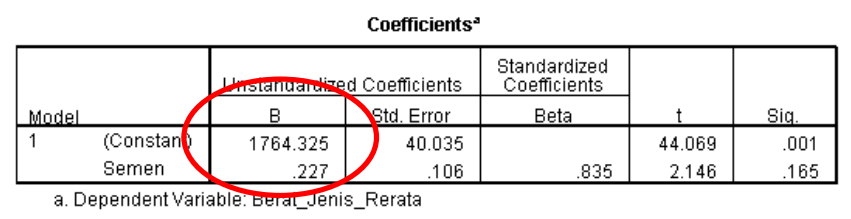

Gambar 4 Hasil analisis mahasiswa dengan aplikasi SPSS 16.0

2. Pembelajaran untuk konsep Korelasi

Berdasarkan evaluasi pembelajaran, mahasiswa sudah menunjukkan pemahaman terhadap hubungan antara dua variabel (variabel terikat dan variabel bebas) dan dapat menghitung berapa besar hubungan tersebut baik secara perhitungan manual dan menggunakan bantuan aplikasi microsoft excel dan SPSS 16.0. Adapun contoh dari jawaban mahasiswa pada salah satu kelompok disajikan pada Gambar 5 dan 6. Data yang diolah mahasiswa masih data yang sama pada Tabel I di atas.

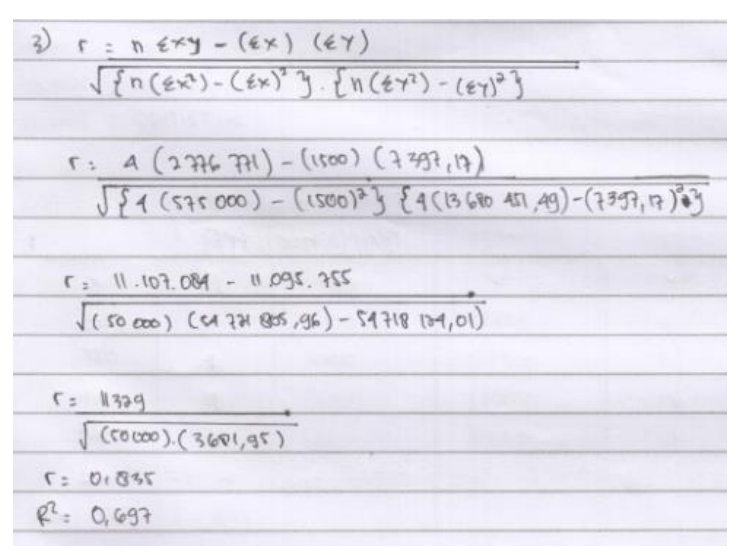

Gambar 5 Hasil analisis nilai r mahasiswa secara manual

Berdasarkan Gambar 5 di atas terlihat bahwa hasil perhitungan yang telah dilakukan oleh salah satu kelompok mahasiswa menunjukkan hasil yang sama dengan Gambar 1 grafik yang diperoleh dari artikel tersebut. Dari gambar grafik memperlihatkan bahwa nilai $\mathrm{r}^{2}$ adalah 0,697. Sehingga jika dibandingkan dengan hasil perhitungan mahasiswa secara manual maka nilai tersebut adalah sama. Mahasiswa juga melakukan analisis dengan bantuan aplikasi microsoft excel dan SPSS 16.0, seperti terlihat pada Gambar 6 dan 7 berikut. Berdasarkan analisis tersebut maka dapat diketahui nilai akhirnya hampir sama dengan hasil pada artikel tersebut.

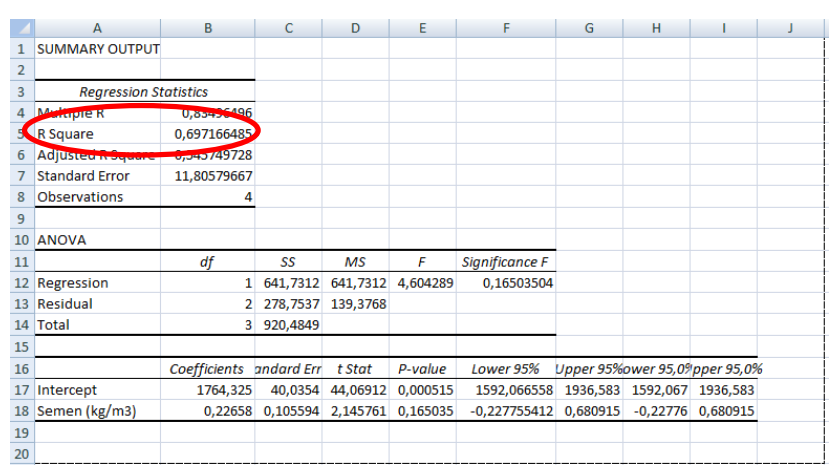

Gambar 6 Hasil analisis mahasiswa dengan aplikasi microsoft excel 


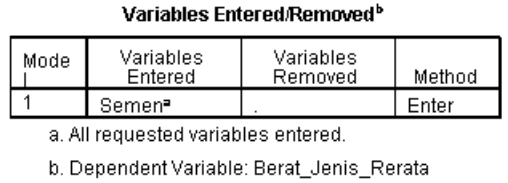

Model Summary

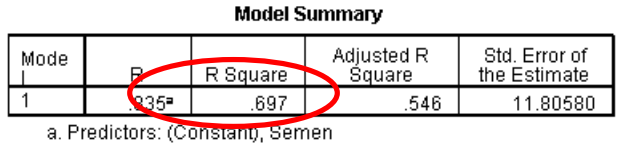

ANOVA ${ }^{\text {b }}$

\begin{tabular}{|ll|r|r|r|r|c|}
\hline Modelel & & $\begin{array}{c}\text { Sum of } \\
\text { Squares }\end{array}$ & \multicolumn{1}{c|}{ df } & Mean Square & F & Sig. \\
\hline 1 & Regression & 641.731 & 1 & 641.731 & 4.604 & $.165^{2}$ \\
& Residual & 278.754 & 2 & 139.377 & & \\
& Total & 920.485 & 3 & & & \\
\hline
\end{tabular}

a. Predictors: (Constant), Semen

b. Dependent Variable: Berat_Jenis_Rerata

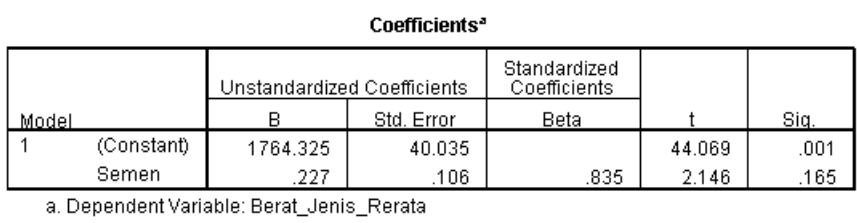

Gambar 7 Hasil analisis mahasiswa dengan aplikasi SPSS 16.0

3. Pembelajaran menemukan grafik dan persamaannya Pada akhir pembelajaran mahasiswa diharapkan bisa menggambar grafik secara manual dengan menghubungkan setiap titik-titik dari data yang ada pada artikel yang telah dipilih. Jawaban mahasiswa masih ada yang salah karena mahasiswa hanya menghubungkan satu titik ke titik yang lainnya tanpa mengerti hubungan antara titik-titik tersebut, dan belum memahami maksud dari angka $\mathrm{R}^{2}$ pada hasil yang telah mereka hitung. Dengan arahan dari dosen, mahasiswa diharapakan mencoba sendiri menggambar diagram tersebut menggunakan aplikasi pengolahan angka. Mahasiswa diminta mengamati diagram tersebut, kemudian dosen meminta mahasiswa menemukan konsep hubungan antara variabel tersebut.

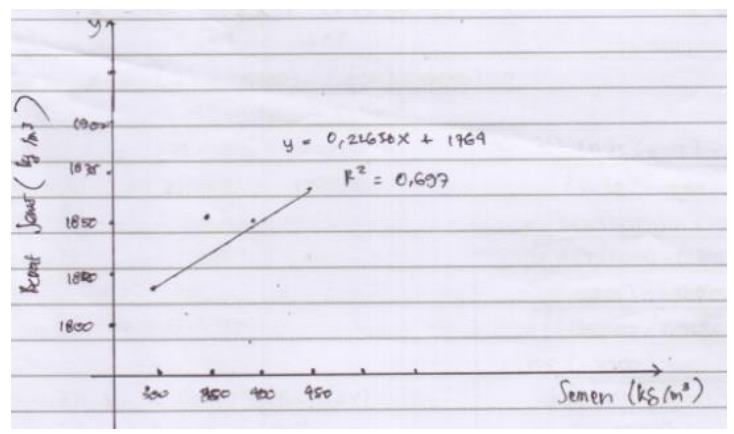

Gambar 8 Hasil grafik manual yang digambar oleh mahasiswa

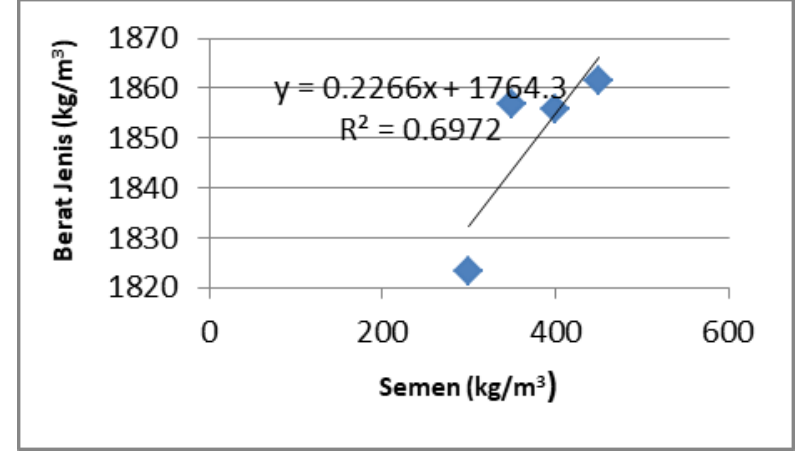

Gambar 9 Hasil grafik dengan aplikasi microsoft excel yang diolah oleh mahasiswa

Dari grafik mahasiswa masih belum mengerti hubungan antara kandungan semen dan berat jenis beton ringan. Hubungan tersebut berbanding lurus, artinya semakin banyak kandungan semen yang digunakan dalam campuran beton ringan akan menyebabkan kenaikan pada berat jenis beton tersebut, dimana semen merupakan elemen yang berfungsi sebagai pengikat agregat dalam beton.

\section{siakad.politap.ac.id/siakad/rep_nilaikuliah}

\begin{tabular}{|c|c|c|c|c|}
\hline \multicolumn{2}{|c|}{$\begin{array}{l}\text { Matas kuliah } \\
\text { Kode Mata kuliah }\end{array}$} & \multicolumn{2}{|l|}{$\begin{array}{l}\text { STATISTIK } \\
\text { PJJ2213 }\end{array}$} & \\
\hline No & NIM & Nama Mahaalewa & $\begin{array}{l}\text { TUGAS } \\
(20 \% \%)\end{array}$ & \\
\hline 1 & 4062018186 & FEBRIYANTO & 98.00 & \\
\hline 2 & 4062018197 & $\begin{array}{l}\text { PURNOMO PUTRA } \\
\text { SANJAYA }\end{array}$ & 98.00 & \\
\hline 3 & $406201818 B$ & RAYGITA PEBRIANA & 98.00 & 1 \\
\hline 4 & 4062018189 & BAYU SETIAWAN & 100.00 & \\
\hline 5 & 4062018190 & CICI SEPTIANI & 100.00 & \\
\hline 8 & 4062018191 & LUTFI CNHYADI & 98.00 & \\
\hline 7 & 4062018192 & NOVIANTO & 98.00 & \\
\hline 8 & 4062018193 & DIDIT PRIANSYAH & 100.00 & \\
\hline 9 & 4062018194 & MLDIAN SETIAWAN & 58.00 & \\
\hline 10 & 4062018195 & DINZ TRI PAMUNGKAS & 83.00 & \\
\hline 11 & 4062018196 & ROSLAN & 98.00 & \\
\hline 12 & 4062018197 & ANGGI PUSPITA & 98.00 & 1 \\
\hline 13 & 4062018198 & ELMA SEPTIANI PUTRI & 100.00 & \\
\hline 14 & 4062018199 & PUTRI DESYA RAMIS & 93.00 & \\
\hline 15 & 4062018200 & SISKA NOVITASARI & 100.00 & 1 \\
\hline 18 & 4062018201 & $\begin{array}{l}\text { M. YYSUF ALDO } \\
\text { ARIANDA }\end{array}$ & 98.00 & \\
\hline 17 & 4062018203 & $\begin{array}{l}\text { MARTINUS YERRI } \\
\text { TRISNO }\end{array}$ & 98.00 & \\
\hline 18 & 4062018204 & FITRINNI. S & 98.00 & \\
\hline 19 & 4062018205 & HERNISA OKTAMIANI & 98.00 & \\
\hline 20 & 4062018206 & $\begin{array}{l}\text { WUHAMMMAD GELIN } \\
\text { RAMADHAN } \\
\end{array}$ & 88.00 & \\
\hline 21 & 4062019207 & WERI YANTO & 98.00 & \\
\hline 22 & $406201820 B$ & ISNIATUN & 100.00 & \\
\hline 23 & 4062018209 & HARIS SNPUTRA & 57.00 & \\
\hline 24 & 4062019210 & FADHLI DZILJALNL ILYAS & 100.00 & \\
\hline 25 & 4062018212 & $\begin{array}{l}\text { GUNAWAN EKO } \\
\text { FERDIYANTO }\end{array}$ & 100.00 & \\
\hline 26 & 4062018213 & ABELL DWI PRAKOSO & 100.00 & \\
\hline 27 & 4062018214 & WIMIK WINARTI & 98.00 & \\
\hline 28 & 4062018215 & INDRA ARYA PRATAMA & 100.00 & \\
\hline 29 & $406201 \mathrm{a} 216$ & SURYA WAHYUDA & 90.00 & \\
\hline
\end{tabular}

Gambar 10. Nilai tugas statistik mahasiswa 


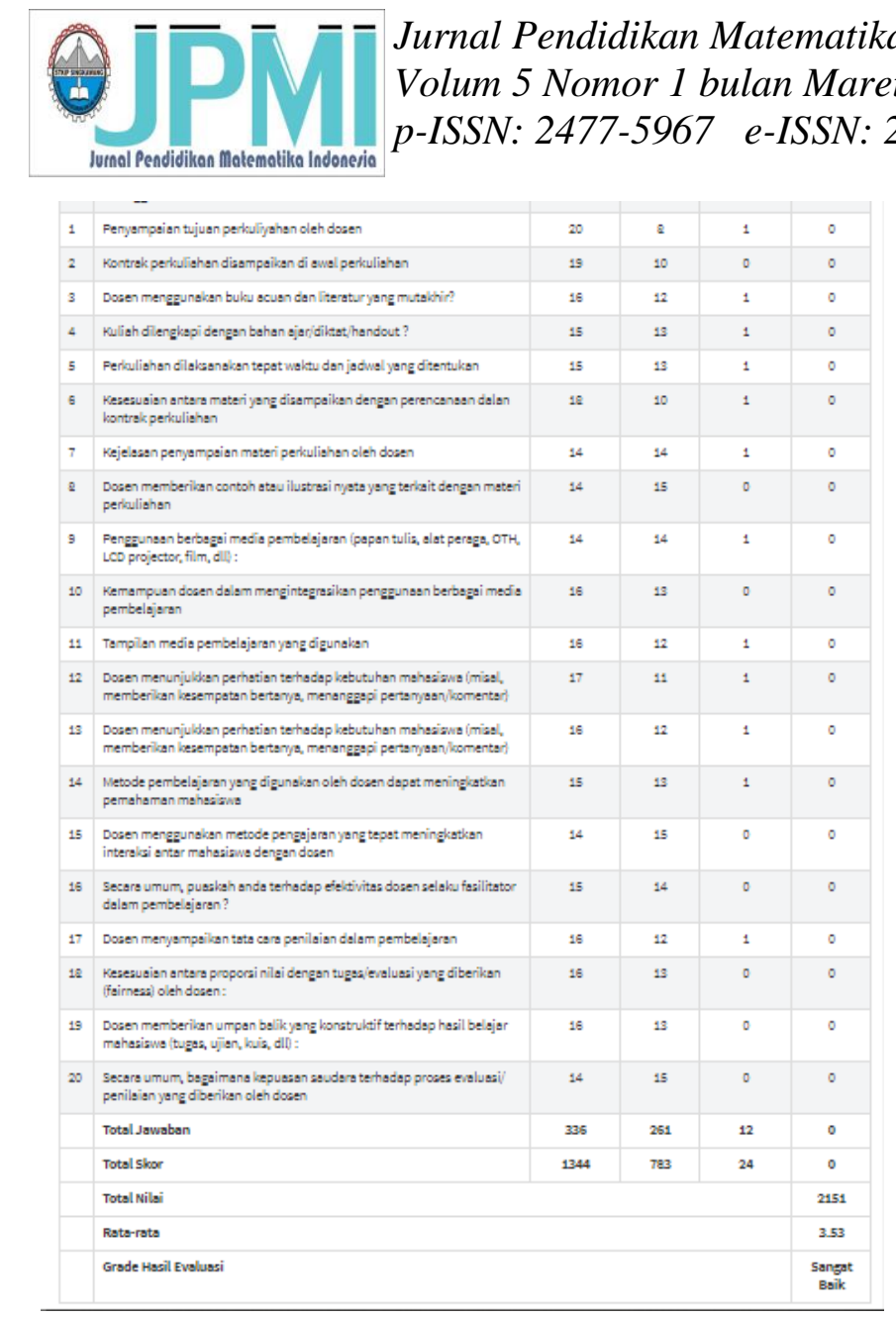

Gambar 11. Rekap kuisioner mata kuliah Statistik

\section{KESIMPULAN}

Deskripsi hasil evaluasi data menunjukkan desain pembelajaran materi persamaan regresi dan korelasi berbasis RME untuk mahasiswa semester dua Program Studi Perancangan Jalan dan Jembatan Jurusan Teknik Sipil yang dirancang sangat mudah dan efektif digunakan dalam meningkatkan kemampuan penalaran matematis mahasiswa dalam proses pembelajaran di kelas. Ini dilihat dari nilai rata-rata tugas yang diperoleh oleh mahasiswa dan kuisioner yang telah diberikan diakhir semester. Sehingga desain pembelajaran tersebut dapat menjadi pedoman untuk dosen dalam mendesain pembelajaran yang diharapkan meningkatkan kemampuan penalaran matematis mahasiswa.

\section{REFERENSI}

Adang Surahman. (2016). Analisis Statistik dan Probabilitas. Fakultas Teknik Sipil dan Lingkungan. Intitusi Teknologi Bandung.
Aris Sustrisno dan Slamet Widodo. (2012). Analisis Variasi Kandungan Semen terhadap Kuat Tekan Beton Ringan Struktural Agregat Pumice. Program Studi Teknik Sipil Fakultas Teknik, Universitas Negeri Yogyakarta.

Edy Tandililing. (2010). Implementasi Realistic Mathematics Education (RME) di Sekolah. Jurnal Untan Vol 25 No. 3, dari http://www.jurnal.untan.ac.id pada tanggal 28 Maret 2019.

Garfield dan Chance. (2000). T Taics Ducat Issues d Challenges, Mathematics Thinking and Learning, 2(1\&2),99-125.

Nana Sudjana. (2009). Penilaian Hasil proses belajar mengajar. Bandung : PT Remaja Rosdakarya.

Nawari. (2010). Analisis Statistik dengan MS Excel 2007 dan SPSS 17. Kompas Gramedia. PT Elex Media Komputindo.

Ratna Sariningsih dan Indri Herdiman. (2017). Mengembangkan Kemampuan Penalaran Statistik dan Berfikir Kreatif Matematis Mahasiswa Melalui Pendekatan Open-ended. Jurnal Pendidikan Matematik, Vol 4 No. 2, dari https://journal.uny.ac.id/index.php/jrpm/article/vie w/16685 pada tanggal 28 Maret 2019.

Siakad. (2019). Politeknik Negeri Ketapang. http://siakad.politap.ac.id.

Soedjadi. (2003). Pembelajaran Matematika berjiwa RME. Makalah seminar Nasional PMRI di Universitas Sanata Dharma. Yogyakarta.

Stanislaus S. Uyanto. (2009). Pedoman Analisis Data dengan SPSS. Graha Ilmu.

Sugiyono. (2006). Statistik untuk Penelitian. Bandung: Alfabeta.

Suryanto. (2007). Pendidikan Realistik Matematika Indonesia (PMRI): dalam PMRI (Pendidikan Realistik Matematika Indonesia). Volume V, No. 1.

Teguh Wahyono. (2013). Belajar Sendiri SPSS 16. Kompas Gramedia. PT Elex Media Komputindo.

Tim Penyusun. (2015). Job Sheet Statistik. Politeknik Negeri Ketapang.

Zulkardi. (2006). RME Suatu Inovasi dalam Pendidikan Matematika di Indonesia. Makalah yang disajikan pada Konperensi Matematika Nasional. Bandung: ITB. 